10. ILO Convention No. 182 at a glance: An introduction to legally prohibiting hazardous work for children. 30.05.2018. URL: https://www.ilo.org/ipec/Informationresources/WCMS_IPEC_PUB_ 30296/lang--en/index.htm

11. ILO proposes policies to end child labour by 2025 . URL: https://www.ilo.org/global/about-the-ilo/newsroom/news/WCMS_ 595716/lang--en/index.htm

DOI https://doi.org/10.30525/978-9934-26-074-2-24

\title{
ОСОБЛИВОСТІ ІНТЕГРАЦІЇ ТРУДОВОГО ПРАВА УКРАЇНИ ІЗ ЗАКОНОДАВСТВОМ ЗАРУБІЖНИХ ДЕРЖАВ
}

\author{
Бутинська Р. Я. \\ кандидат юридичних наук, \\ старший викладач кафедри господарсько-правових дисциплін \\ Львівського державного університету внутрішніх справ \\ м. Львів, Украӥна
}

В умовах глобальної економічної кризи інтеграція трудового права $\epsilon$ видом зближення правових систем, отже, по-перше, може бути спрямована на досягнення як схожого, так й одноманітного правового регулювання. По-друге, оскільки трудова інтеграція держав є складовою частиною єдиної соціальної політики держав-учасників спільного ринку праці, вона може здійснюватися тільки за допомогою міжнародних засобів, тобто укладення міжнародних договорів й імплементації актів міжнародних організацій, завдяки чому й реалізується загальна соціальна політика.

Економічна інтеграція призвела до усвідомлення необхідності створити та ввести в дію уніфіковані соціальні стандарти. I починаючи із 70-х років XX ст. було ухвалено чимало важливих директив у сфері найманої праці з питань рівного ставлення, професійної безпеки працівників, консультування та інформування працівників у разі масових вивільнень, захисту прав працівників за умов неплатоспроможності роботодавця чи охорони прав працівників у випадку передачі підприємств, бізнесу або частин підприємств чи бізнесу [1, с. 298]. Вказаний період у контексті розвитку трудового права СС вважають дуже продуктивним та іменують його часом «гармонізації» правового регулювання [2, с. 5]. 
У міжнародних відносинах існує практика, що держави, які беруть участь в економічній інтеграції і створили єдиний ринок праці на своїх територіях, роблять деякі дії, спрямовані на досягнення подібності в регулюванні трудових відносин. Доказом цього є тексти міжнародних договорів, присвячених економічній інтеграції, більшість 3 яких містить положення про зближення, гармонізацію або уніфікацію трудового законодавства.

У цьому аспекті потрібно розмежувати поняття зближення, гармонізації та уніфікації законодавства, а також стандартизації та імплементації, адже єдиного усталеного їх розуміння немає поки ні на практиці, ні у вітчизняній чи зарубіжній літературі. А втім, більшість наведених понять розуміють як взаємодію держав, спрямовану на досягнення подібності в правовому регулюванні однотипних суспільних відносин. Імплементацію та стандартизацію трактують дещо інакше. Під імплементацією норм міжнародного права більшість авторів розуміє поведінку держав, яка спрямована на реалізацію цілей міжнародних норм і виражається у відповідних діях або в утриманні від дій [3, с. 397]. Імплементація охоплює дві стадії: трансформацію міжнародно-правових норм у норми національного права i їх реалізацію. При цьому незалежно від суб'єктивної позиції держави трансформаційний процес об'єктивно відбувається за наявності остаточної згоди держави на обов'язковість для нього міжнародного договору (у формі ратифікації тощо). Отже, імплементація $є$ одним з етапів досягнення подібності у правовому регулюванні державами однотипних суспільних відносин, зокрема й у сфері праці шляхом реалізації норм дво- або багатостороннього міжнародного договору чи конвенцій міжнародної організації.

Щодо понять зближення, гармонізації та уніфікації законодавства, потрібно передусім уточнити: теоретично правильніше говорити про зближення, гармонізацію та уніфікацію правових систем, а не законодавства. Це пов'язано з тим, що подібності в регулюванні однотипних суспільних відносин держави досягають не тільки і не стільки через трансформаційні зміни свого законодавства, скільки в підсумку укладення міжнародних договорів. Разом з тим міжнародний договір, згідно з Конституцією України, є складовою частиною ії правової системи [4].

Саме поняття «правова системи система» в літературі розглядають у вузькому і широкому розумінні. У вузькому значенні правова система це «структурно і функціонально упорядкований масив взаємопов'язаних нормативно-правових актів, що створюються і діють на основі єдиних принципів», тобто позитивне право. У широкому - «це все позитивне право, що розглядається в єдності з активними елементами правової дійсності - правової ідеології і судової (юридичної) практики» [5, с. 211]. 
У нашому випадку поняття правової системи використовуємо у вузькому значенні, тобто як сукупність чинних на основі єдиних принципів норм права, що містяться в нормативних правових актах $\mathrm{i}$ нормативних договорах держави.

Дихотомічний розподіл обсягу поняття зближення правових систем за критерієм досягнення (недосягнення) однаковості дає змогу позначити два види зближення: спрямоване на однакове правове регулювання i спрямоване на подібне, але враховує національні особливості правового регулювання. Тобто зближення правових систем, спрямоване на єдинообразне правове регулювання, слід іменувати уніфікацією правових систем. Уніфікація права $є$ рухом до гармонійної взаємодії різних правових систем. Зближення правових систем, спрямоване на досягнення подібного, гармонійного, але не однакового правового регулювання, закономірно називають гармонізацією правових систем. Отже, поняття зближення правових систем є родовим щодо понять гармонізації та уніфікації правових систем.

Що стосується методів зближення правових систем, то можна навести п'ять:

1. Рецепція, тобто прийняття окремими державами нормативних актів на основі обліку законодавства інших держав або шляхом запозичення законодавчих конструкцій із законодавства інших держав.

2. Прийняття окремими державами нормативних актів, що відтворюють положення будь-якої конвенції без їі ратифікації. У цьому випадку норми, що містяться в конвенціях, являють собою деякою мірою довідковий матеріал, до якого зазвичай звертаються держави, і ці норми частково відіграють у соціальній сфері роль загального міжнародного права (droit commun nationale). Як приклад служить можна навести відтворення в чинному законодавстві положень Свропейської соціальної хартії задовго до їі ратифікації.

Аналогічно відбувається зближення правових систем за допомогою відтворення в національному законодавстві положень модельного акта.

3. Кодифікація законодавства. Це діяльність компетентних державних органів $з$ переробки несистематизованого правового масиву і створення нових нормативних правових актів, що містять взаємопов'язані норми. Такий процес здійснюється у сфері взаємовпливу і взаємозбагачення правових культур і систем. Створення в різних державах однакових правових норм внаслідок впливу різних правових систем одна на одну $є$ зближенням без використання міжнародно-правових засобів.

4. Імплементація актів міжнародних організацій. Ідеться, наприклад, про імплементації державами-учасниками Європейського Союзу (далі - ЄС) прийнятих органами ЄС директив, присвячених 
регулюванню трудових відносин. Окремим випадком зближення правових систем, що досягається за допомогою вказаного методу, $є$ ратифікація конвенцій Міжнародної організації праці (далі - МОП). Річ у тому, що конвенції МОП не є класичними міжнародними договорами. Останніми називають угоди між двома або більше державами, які $з$ огляду на свій суверенітет здатні надати міжнародному праву обов'язковий характер. Двосторонні міжнародні договори у сфері праці, що передбачають зближення правових систем, приймаються, як правило, 3 окремих питань, що стосуються співробітництва держав, наприклад, з питань трудової міграції. Конвенції МОП - це міжнародні договори, укладені в рамках міжнародних організацій. Вони приймаються на Міжнародній конференції праці і набувають чинності через рік після того, як іії ратифікує необхідна кількість членів Конвенції.

5. Висновок міжнародного договору. Зближення правових систем конвенційним шляхом $\epsilon$ одним 3 найпоширеніших у міжнародній практиці способів зближення. Виокремлюють дві його основні форми: інкорпорація відповідних правил у текст інтегральної конвенції (convention integrale) і виклад їх у вигляді однакового закону (loi uniforme), що становить додаток до конвенції.

При використанні першої форми договірні держави зобов'язуються застосовувати правила, сформульовані у відповідних статтях конвенції, при використанні другої - ввести в дію на своїх територіях прийнятий на основі міжнародної конвенції нормативний акт. Заразом, як зазначає Р. Давид, важливо розрізняти традиційні положення, що стосуються зобов'язань держав, та однакові приписи, що заторкують безпосередньо приватних осіб і містяться в однаковому акті, який є додатком до конвенції [6].

Аналіз літератури дає підстави для висновку, що зближення правових систем давно відомо міжнародній практиці. Р. Давид писав, що трудове право і право соціального забезпечення різних країн «мають чимало схожого в законодавчих тенденціях, збігів не тільки у великих питаннях, але і в юридичних деталях. Протягом двадцяти, десяти років і навіть в більш стислі терміни реформу, яка проведена в будь-якій країні і довела свою доцільність, повторять в інших країнах 3 деякими модифікаціями, що відображають специфічні етичні умови цих країн або спрямовані на ліквідацію прогалин і недоліків першого законодавчого рішення» [6]. Велику роль у зближенні національних правових систем зіграла діяльність різних міжнародних організацій, зокрема МОП зі створення та просування міжнародних трудових стандартів.

Підбиваючи підсумок, наведемо власне визначення поняття трудоправової інтеграції держав: це здійснювана шляхом укладення 
міжнародних договорів або імплементації актів міжнародних організацій взаємодія держав-учасниць спільного ринку, спрямована на досягнення схожого або однакового регулювання трудових відносин.

\title{
Література:
}

1. Рим О. М. Виникнення та розвиток трудового права Європейського Союзу. Вісник Львівського торговельно-економічного університету. Юридичні науки. 2018. Вип. 7. С. 297-306.

2. Baden-Baden: Nomos Verlagsgesellschaft : München : Verlag C. H. Beck : Oxford, United Kingdom : Hart Publishing, 2018. 209 p.

3. Терлецький Д. С. Трансформація, інкорпорація та імплементація норм міжнародного права: теоретичний аналіз. Молодий вчений. 2017. Лип. № 7 (47). С. 395-400.

4. Конституція України: Закон від 28.06.1996 № 254к/96-ВР. База даних «Законодавство України» / ВР України. URL: https://zakon.rada.gov.ua/laws/show/254\%D0\%BA/96-\%D0\%B2\%D1 \%80\#Техt (дата звернення: 17.01.2021).

5. Правова система України: історія, стан та перспективи: в 5 т. / за заг. ред. М. В. Цвіка, О. В. Петришина. Харків, 2008. Т. 1: Методологічні та історико-теоретичні проблеми формування та розвитку правової системи України. 728 с.

6. Давид Р., Жоффре-Спинози К. Основные правовые системы современности / пер. с фр. В. А. Туманова. Москва, 1999. 400 с.

DOI https://doi.org/10.30525/978-9934-26-074-2-25

\section{ШТУЧНИЙ ІНТЕЛЕКТ І ТРУДОВІ ВІДНОСИНИ: ВПЛИВ І ВЗАСМОДІЯ}

\author{
Гущу С. Ф. \\ orcid.org/0000-0003-1373-6079 \\ кандидат юридичних наук, доцент, \\ дочент кафедри права \\ гуманітарно-правового факультету \\ Національного аерокосмічного університету імені М. С. Жуковського \\ «Харківський авіаційний інститут» \\ м. Харків, Україна
}

Впровадження штучного інтелекту в економічні і соціальні процеси безумовно впливають на відносини між працівником і роботодавцем. 